\title{
STARTING-UP OF KNITTING MACHINES WITH PRESTRESSED DRIVE CONNECTIONS
}

Introduction. One of the most significant factors affecting the knitting machines' operation efficiency is represented by dynamic forces arising when transitional modes (starting, braking, mechanisms' switching, etc.) [1...3]. The dynamic analysis of machines in order to find the dynamic overloads coefficients is of high importance to solve the current problem of improving the knitting machines efficiency (increasing machine productivity and the produced tissue quality).

Analysis of recent research and publications. Modern dynamic analysis of machines [1...4] is effected in order to calculate the mechanical systems' dynamic parameters associated with significant expenses reducing the effectiveness of existing dynamic analysis methods.

The research object relates to elaborating the dynamic analysis method for mechanical system which analytical model can be represented as three-mass in-line system with first driving host of weight at drive's prestressed elastic connections. This problem solving we used modern methods of theoretical research based on the mechanical systems' dynamics theory and the theory of elasticity.

This research goal. Given the urgency of improving the knitting machines' efficiency by reducing the dynamic loads, the purpose of the present research refers to amelioration of dynamic analysis method applicable to knitting machines with pre-strained drive linking.

Problem statement. According to studies [1...3] and others, at dynamic processes' analysis most knitting manually-operated and automatic machines can be presented as equivalent to three-systems where the first leading mass has prestressed connections with the initial conditions of motion

$$
T_{(12) 0}=T_{2}+T_{3} ; T_{(23) 0}=T_{3} ; \dot{T}_{(12) 0}=0 ; \dot{T}_{(23) 0}=0 ; T_{(1) 0}=T_{1},
$$

where $T_{(1) 0}, T_{1}$ - initial and starting ccouples applied to the first mass;

$T_{2}, T_{3}$ - resistance couples applied to the system's $2^{\text {nd }}$ and $3^{\text {rd }}$ masses;

$T_{(12) 0} ; T_{(23) 0} ; \dot{T}_{(12) 0} ; \dot{T}_{(23) 0}$ - initial values of $C_{12}, C_{23}$ system's linkages elasticity couples and their respective first derivatives..

The effected studies have shown that the specified conditions of dynamic processes present, it is possible to simplify significantly the existing methods of calculating the coefficient of sytem's masses elastic connections' dynamic loads that requires to define the four cosine amplitudes in solving differential equations of mechanical system motion.

Considering the correlation betwwen three-mass system frequency fluctuations and the proper vibration frequencies corresponding to two-mass systems. The equation of three-mass system motion can be written in the form [1] (dissipative forces are not included)

$$
\begin{aligned}
& p^{2} T_{12}+\beta_{12}^{2} T_{12}-\frac{C_{12}}{J_{2}} T_{23}=\frac{C_{12}}{J_{1}} T_{1}+\frac{C_{12}}{J_{2}} T_{2}, \\
& p^{2} T_{23}+\beta_{23}^{2} T_{23}-\frac{C_{23}}{J_{2}} T_{12}=\frac{C_{23}}{J_{3}} T_{3}+\frac{C_{23}}{J_{2}} T_{2},
\end{aligned}
$$

wheree $\beta_{12}^{2}, \beta_{23}^{2}$ - two-mass systems' proper frequencies:

\author{
DOI: 10.15276/opu.1.43.2014.16
}

(C) V.V. Chaban, B.F. Pipa, 2014

МАШИНОБУДУВАННЯ. ТЕХНОЛОГІЯ МЕТАЛІВ. МАТЕРІАЛОЗНАВСТВО 


$$
\beta_{12}^{2}=C_{12} \frac{J_{1}+J_{2}}{J_{1} J_{2}}, \beta_{23}^{2}=C_{23} \frac{J_{2}+J_{3}}{J_{2} J_{3}} ;
$$

$p$ - differentiation symbol;

$J_{1}, J_{2}, J_{3}$ - respective system masses' inertial couples.

Through solving the differential equations system (2) in the form $T_{i}=A_{i} \sin (\omega t+\varphi)$, we obtain the characteristic equation [1]

or

$$
\begin{gathered}
\left|\begin{array}{cc}
\beta_{12}^{2}-\omega^{2} & -\frac{C_{12}}{j_{2}} \\
-\frac{C_{23}}{J_{2}} & \beta_{23}^{2}-\omega^{2}
\end{array}\right|=0, \\
\omega^{4}-\left(\beta_{12}^{2}+\beta_{23}^{2}\right) \omega^{2}+\beta_{12}^{2} \beta_{23}^{2}-\frac{C_{12} C_{23}}{J_{2}^{2}}=0 .
\end{gathered}
$$

In accordance with the theorem of positivity and characteristic equiation roots' separation, the equation roots (5) are positive and separated with minor roots, that corresponds to the first element [1]. The minor root corresponding to the first element of the determinant (4) is:

$$
\omega^{2}=\beta_{23}^{2} \text {. }
$$

Then

$$
\omega_{1}^{2}>\beta_{23}^{2}>\omega_{2}^{2}>0 \text {. }
$$

In accordance with the Viyeta formulas the polynomial roots' sum, taken with the opposite sign, is equal to the coefficient when $\omega^{2}$ at (5), and the roots product is equal to the free member, ie

$$
\begin{gathered}
\omega_{1}^{2}+\omega_{2}^{2}=\beta_{12}^{2}+\beta_{23}^{2}, \\
\omega_{1}^{2} \omega_{2}^{2}=\beta_{12}^{2} \beta_{23}^{2}-\frac{C_{12} C_{23}}{J_{2}^{2}} .
\end{gathered}
$$

Let we show further that the frequency property expressed through an inequality (6) can be extended up to inequality

$$
\omega_{1}^{2}>\beta_{12}^{2}>\beta_{23}^{2}>\omega_{2}^{2}>0 .
$$

Reformulating equation (7), we substitute $\omega_{2}^{2}$ with; now considering that $\omega_{2}^{2}<\beta_{23}^{2}$, according to (6) we get

$$
\omega_{1}^{2}+\beta_{23}^{2}>\beta_{12}^{2}+\beta_{23}^{2} .
$$

Trimming $\beta_{23}^{2}$, at (9), we obtain $\omega_{1}^{2}>\beta_{12}^{2}$. Then replacing $\omega_{1}^{2} w i t h \beta_{23}^{2}$, at equation (7), taking into account that $\omega_{1}^{2}>\beta_{23}^{2}$ as issues from from (6) we have

$$
\beta_{23}^{2}+\omega_{2}^{2}<\beta_{12}^{2}+\beta_{23}^{2} \text {. }
$$

From (10) we observe that $\omega_{2}^{2}<\beta_{12}^{2}$. So, $\beta_{12}^{2}$ exceeds the lesser three-mass system's frequency $\omega_{2}$ but is below of the greater $\omega_{1}$ one. Given that $\beta_{12}^{2}>\beta_{23}^{2}$, we get the inequality (8), which shows that most of the three-mass system elasticity couples' frequencies is greater than most of the two-mass systems' proper vibrations frequency, and the lower three-mass system's frequency is less than the lower of two-mass system frequencies. 
The obtained dependences (7), (8) can be used to verify the accuracy of $\omega_{i}$ determining as well as for analysis of expression obtained when solving the equations of considered masses' motion.

Solution of differential equations (2) with initial conditions (1) has the following form [1]

$$
\begin{aligned}
& T_{12}=A_{(12) 1} \cos \omega_{1} t+A_{(12) 2} \cos \omega_{2} t+a_{12}, \\
& T_{23}=A_{(23) 1} \cos \omega_{1} t+A_{(23) 2} \cos \omega_{2} t+a_{23},
\end{aligned}
$$

where $a_{12}=\frac{T_{1}\left(J_{2}+J_{3}\right)+J_{1}\left(T_{2}+T_{3}\right)}{J_{1}+J_{2}+J_{3}}$;

$$
a_{23}=\frac{J_{3}\left(T_{1}-T_{2}\right)+T_{3}\left(J_{1}+J_{2}\right)}{J_{1}+J_{2}+J_{3}} .
$$

According to the initial conditions (1) at $t=0$

$$
\begin{aligned}
& T_{(12) 0}=A_{(12) 1}+A_{(12) 2}+a_{12} ; \\
& T_{(23) 0}=A_{(23) 1}+A_{(23) 2}+a_{23} .
\end{aligned}
$$

The maximum possible value of the dynamic coefficient according to (11)

$$
\begin{aligned}
K_{12} & =\frac{a_{12}+\left|A_{(12) 1}\right|+\left|A_{(12) 2}\right|}{T_{2}+T_{3}} ; \\
K_{23} & =\frac{a_{23}+\left|A_{(23) 1}\right|+\left|A_{(23) 2}\right|}{T_{3}} .
\end{aligned}
$$

Value amplitudes are expressed in cosine dependences [1]

$$
K_{1}=\frac{A_{(23) 1}}{A_{(12) 1}}=\frac{J_{2}\left(\beta_{12}^{2}-\omega_{1}^{2}\right)}{C_{12}}, K_{2}=\frac{A_{(23) 2}}{A_{(12) 2}}=\frac{J_{2}\left(\beta_{12}^{2}-\omega_{2}^{2}\right)}{C_{12}} .
$$

Let we reformulate equations (14),(15) taking into account (18).

$$
\begin{gathered}
A_{(12) 1}+A_{(12) 2}=-a_{12}+T_{(12) 0}, \\
K_{1} A_{(12) 1}+K_{2} A_{(12) 2}=-a_{23}+T_{(23) 0} .
\end{gathered}
$$

When $\omega_{1}>\omega_{2}\left(\beta_{12}^{2}>\beta_{23}^{2}\right)$, according to (8), from (18)

$$
K_{1}<0, K_{2}>0 \text {. }
$$

Reformulating the (19) considering the (20)

$$
\begin{gathered}
A_{(12) 1}+A_{(12) 2}=-\left(a_{12}-T_{(12) 0}\right), \\
-\left|K_{1}\right| A_{(12) 1}+\left|K_{2}\right| A_{(12) 2}=-\left(a_{23}+T_{(23) 0}\right) .
\end{gathered}
$$

We can solve the algebraic equations system (21)

$$
\begin{aligned}
& A_{(12) 1}=\frac{-\left(a_{12}-T_{(12) 0}\right)\left|K_{2}\right|+\left(a_{23}-T_{(23) 0}\right)}{\left|K_{1}\right|+\left|K_{2}\right|}, \\
& A_{(12) 2}=\frac{-\left(a_{23}-T_{(23) 0}\right)-\left(a_{12}-T_{(12) 0}\right)\left|K_{1}\right|}{\left|K_{1}\right|+\left|K_{2}\right|} .
\end{aligned}
$$

Analyzing (22), we conclude that $A_{(12) 1}<0, A_{(12) 2}<0$, as for systems considered under initially adopted conditions we have $\left(a_{12}-T_{(12) 0}\right)>\left(a_{23}-T_{(23) 0}\right)$ and $\left|K_{2}\right|>1$.

As usually, the $\omega_{1}>\omega_{2}$ then 


$$
A_{(12) 1}<0, A_{(12) 2}<0 ; A_{(23) 1}=-\left|K_{1}\right| A_{(12) 1}>0 ; A_{(23) 2}=\left|K_{2}\right| A_{(12) 2}<0 .
$$

Given the amplitudes' signs, we obtain from equations (14), (15):

$$
\begin{gathered}
\left|A_{(12) 1}\right|+\left|A_{(12) 2}\right|=a_{12}-T_{(12) 0}, \\
\left|A_{(23) 1}\right|+\left|A_{(23) 2}\right|=a_{23}-T_{(23) 0}+2 K_{1} A_{(12) 1}
\end{gathered}
$$

Substituting with (24) at (16), (17) and developing the $K_{1}$ and $A_{(12) 1}$ :

$$
\begin{aligned}
& K_{12}=\frac{2 a_{12}-T_{(12) 0}}{T_{2}+T_{3}}, \\
& K_{23}=\frac{2 a_{23}-T_{(23) 0}+2 K_{1} A_{(12) 1}}{T_{3}}=\frac{2 K_{2}\left(T_{(12) 0}-a_{12}\right)+\left(2 a_{23}-T_{(23) 0}\right) \mu-T_{(23) 0}}{T_{3}(\mu-1)},
\end{aligned}
$$

where $\mu=\frac{\beta_{12}^{2}-\omega_{2}^{2}}{\beta_{12}^{2}-\omega_{1}^{2}}$.

Results obtained. The equations (25) allows to obtain the dynamic system coefficients without finding amplitude of mass vibration, thus significantly reducing the calculations.

The frequency of system's masses vibrations shall be found using the characteristic equation (5):

$$
\omega_{1,2}^{2}=\lambda \pm \sqrt{\lambda^{2}-C_{12} C_{23} \frac{J_{1}+J_{2}+J_{3}}{J_{1} J_{2} J_{3}}},
$$

where $\lambda=\frac{C_{12}\left(J_{1}+J_{2}\right)}{2 J_{1} J_{2}}+\frac{C_{23}\left(J_{2}+J_{3}\right)}{2 J_{2} J_{3}}$.

Using the results obtained, we can find the dynamic coefficients emerging at round-knitting machine KO-2 during start-up when drive connections prestressed. Here the initial data are such (research results as by [4]): $T_{(12) 0}=24,31 \mathrm{Nm} ; T_{2}=4,4 \mathrm{Nm} ; T_{3}=17,7 \mathrm{Nm} ; T_{(23) 0}=T_{3}=17,7 \mathrm{Nm}$; $J_{1}=0,023 \mathrm{kgm}^{2} ; J_{2}=0,041 \mathrm{kgm}^{2} ; J_{3}=0,021 \mathrm{kgm}^{2} ; C_{12}=1940 \mathrm{Nm} / \mathrm{rad} ; C_{23}=3062 \mathrm{Nm} / \mathrm{rad}$.

Substituting the initial data with equations (12), (13), we find: $a_{12}=23,6 \mathrm{Nm} ; a_{23}=18,24 \mathrm{Nm}$.

The frequency of system masses' variation, according to (27), (28)

$$
\begin{aligned}
& \omega_{1}^{2}=250283,5 \mathrm{c}^{-2} ; \omega_{1}=500,3 \mathrm{c}^{-1} ; \\
& \omega_{2}^{2}=101873,8 \mathrm{c}^{-2} ; \omega_{2}=319,2 \mathrm{c}^{-1} .
\end{aligned}
$$

Applying the initial data and results obtained from (3), (18), (26)

$$
\beta_{12}^{2}=131664,9 ; K_{2}=0,63 ; \mu=-0,25 \text {. }
$$

Replacing the data at equation (25) with results obtained, we find the dynamic coefficients of round-knitting machine KO-2 drive (dynamic overload of the drive elastic connections): $K_{12}=1,13$; $K_{23}=1,1$.

The obtained results are consistent with the issues of calculations using the known methods of mechanical systems' dynamic analysis [1...4]. However, in contrast to the known methods the proposed one, in our opinion, is more effective.

Conclusions. Analyzing the research results, we conclude that the proposed method can more efficiently solve the problem of dynamic analysis of any mechanical system which dynamics model can be represented as three-mass in-line system with first leading mass when prestressed elastic connections.

The obtained equations allow to find the dynamic overload coefficients for elastic connections of mechanical systems drive (including knitting operated and automatic machines) without preliminary calculating the amplitude of the system mass vibration, that significantly reduces the calculations. 


\section{Literature}

1. Піпа, Б.Ф. Динаміка круглов’язальних машин: Моногр. / Б.Ф. Піпа, О.М. Хомяк, Г.І. Павленко; Київ. нац. ун-т технологій та дизайну. - К., 2005. — 293 с.

2. Хомяк, О.М. Динаміка плосков'язальних машин та автоматів: Моногр. / О.М. Хомяк; Київ. нац. ун-т технологій та дизайну. — К: КНУТД, 2008. - 249 с.

3. Чабан, В.В. Динаміка основов’язальних машин: Моногр. / В.В. Чабан, Л.А. Бакан, Б.Ф. Піпа; Київ. нац. ун-т технологій та дизайну. - К.: КНУТД, 2012. - 286 с.

4. Піпа, Б.Ф. Пуск круглов'язальної машини 3 попередньо напруженими в'язями привода / Б.Ф. Піпа, С.О. Ловейкіна // Вісник КНУТД. - 2002. - № 1. - С. $100-103$.

\section{References}

1. Pipa, B.F. Dynamika kruhloviazalnykh mashyn : Monohr. [Circular knitter dynamics: Monogr.] / B.F. Pipa, O.M. Khomiak, H.I. Pavlenko; Kyiv. nats. un-t tekhnolohii ta dyzainu [Kyiv. Nat. Univ. of Technology and Design]. - Kyiv, 2005. - 293 p.

2. Khomiak, O.M. Dynamika ploskoviazalnykh mashyn ta avtomativ: Monohr. [Dynamics of flat knitting machines and automata: Monogr.] / O.M. Khomiak; Kyiv. nats. un-t tekhnolohii ta dyzainu. [Kyiv. Nat. Univ. of Technology and Design]. - Kyiv, 2008. - 249 p.

3. Chaban, V.V. Dynamika osnovoviazalnykh mashyn: Monohr. [Dynamics of warp-knitting machines: Monogr.] /V.V. Chaban, L.A. Bakan, B.F. Pipa; Kyiv. nats. un-t tekhnolohii ta dyzainu[Kyiv. Nat. Univ. of Technology and Design]. - Kyiv, 2012. - 286 p.

4. Pipa, B.F. Pusk kruhloviazalnoi mashyny z poperedno napruzhenymy viaziamy pryvoda [Starting of circular knitter with pretensioned drive linkages] / B.F. Pipa, S.O. Loveikina // Visnyk KNUTD [Bulletin of KNUTD]. - 2002. — \#1. - pp. $100-103$.

\section{AНОТАЦІЯ / АННОТАЦИЯ / ABSTRACT}

В.В. Чабан, Б. Ф. Піпа. Пуск в'язальних машин з попередньо напруженими в'язями привода. Розглядається удосконалення методу динамічного розрахунку коефіцієнтів динамічності механічних систем, динамічна модель яких може бути представлена тримасовою рядною системою з першою ведучою масою при попередньо напружених пружних в'язях привода. При проведенні досліджень використовувалися сучасні методи теоретичних досліджень, що базуються на теорії динаміки механічних систем та теорії пружності. Запропоновано більш досконалий метод знаходження коефіцієнтів динамічності. Одержано рівняння, які дозволяють знаходити коефіцієнти динамічних перевантажень пружних в'язей привода механічних систем без знаходження амплітуд коливань мас системи, що суттєво скорочує розрахунки.

Ключові слова: в'язальна машина, пуск в'язальної машини, динамічні навантаження, коефіцієнт динамічності.

B.В. Чабан, Б.Ф. Пипа. Пуск вязальных машин с предварительно напряженными связями привода. Рассматривается усовершенствование метода динамического расчета коэффициентов динамичности механических систем, динамическая модель которых может быть представлена трехмассовой рядной системой с первой ведущей массой при предварительном напряжении упругих связей привода. При проведении исследования использовались современные методы теоретических исследований, которые основываются на теории динамики механических систем и теории упругости. Предложен более совершенный метод нахождения коэффициентов динамичности. Получены уравнения, позволяющие находить коэффициенты динамических перегрузок упругих связей привода механических систем без нахождения амплитуд колебаний масс системы, что существенно сокращает расчеты.

Ключевые слова: вязальная машина, пуск вязальной машины, динамические нагрузки, коэффициент динамичности.

V.V. Chaban, B.F. Pipa. Starting-up of knitting machines with prestressed drive connections. The article is sanctified to improve method of dynamic calculation of dynamic coefficients of the mechanical systems, the dynamical model of which can be presented by the three-mass row system with the first leading mass at preliminary tension of resilient connections of drive. The study used modern methods of theoretical studies, which are based on the theory of the dynamics of mechanical systems and the theory of elasticity. More perfect method of the dynamical coefficients finding is suggested. Obtained equations allow finding the coefficients of dynamic overloads of resilient connections of the mechanical systems drive without finding amplitudes of vibrations of the system masses that significantly reduces calculations.

Keywords: knitting machine, starting of knitting machine, dynamical loads, dynamical coefficient.

Reviever Dr. techn. sciences, Prof. of Odesa nat. polytechnic univ. Suryaninov N.G.

Received May 5, 2014 